\title{
A systems thinking approach for eliciting mental models from visual boundary objects in hydropolitical contexts: a case study from the Pilcomayo River Basin
}

\author{
Riveraine S. Walters $^{1}$, Erin S. Kenzie ${ }^{2}$, Alexander E. Metzger $^{3}$, William Jesse Baltutis $^{4}$, Kakali B. Chakrabarti $^{5}$, Shana Lee Hirsch ${ }^{6}$ \\ and Bethany K. Laursen ${ }^{7,8,9}$
}

\begin{abstract}
Transboundary collaborations related to international freshwater are critical for ensuring equitable, efficient, and sustainable shared access to our planet's most fundamental resources. Visual artifacts, such as knowledge maps, functioning as boundary objects, are used in hydropolitical contexts to convey understandings and facilitate discussion across scales about challenges and opportunities from multiple perspectives. Such focal points for discussion are valuable in creating shared, socially negotiated priorities and integrating diverse and often disparate cultural perspectives that naturally exist in the context of international transboundary water resources. Visual boundary objects can also represent the collective mental models of the actor countries and transboundary institutions and encompass their perspectives on the complex hydro-social cycles within specific "problem-shed" regions of the shared resources. To investigate and synthesize these multiple concepts, we developed a novel method of eliciting mental models from visual boundary objects in social-ecological contexts by combining content analysis with theoretical frameworks for boundary objects and systems thinking. Using this method, we analyzed visual boundary objects represented in publicly available documents formally related to decision making in the Pilcomayo River Basin in South America. The Pilcomayo River Basin is a unique case for investigating decision making in international collaboration among represented states, given the unique social and biophysical challenges that have plagued the region for over a century. Using our framework, we were able to develop insight into the collective mental models of stakeholders, organizations, and decision-making institutions, related to priorities, vulnerabilities, and adaptation strategies among the various socioeconomic, cultural, political, and biophysical drivers for different regions and scales of the basin.
\end{abstract}

Key Words: boundary objects; hydropolitics; mental models; social-ecological systems; systems thinking

\section{INTRODUCTION}

Hydropolitics, defined as relating "to the ability of geopolitical institutions to manage shared water resources in a politically sustainable manner, i.e., without tensions or conflict between political entities" (UNEP 2007:22) has been considered to be wicked (Rittel and Webber 1973), messy (Ackoff 1979), tangled (Dawes et al. 2009), and even slippery (Rothman 1995) by various practitioners and academics. As such, political disputes between states over shared international rivers are in fact quite common (Dinar 2007). At a deeper level, the main reason is that hydropolitics is based on social values associated with water, which are conditioned considerably by culture (Faure and Sjostedt 1993, Turton and Henwood 2002). Blatter et al. (2001:14) defined culture as "the shared normative-cognitive beliefs, or worldviews, of a social community, rather than the accreted sediment of previous experience." According to this view, culture can also be referred to as a shared mental model (Cabrera and Cabrera 2015), which does not imply an identical mental model, but refers to "compatible mental models that lead to common expectations" (Jensen and Kushniruk 2016:252).

Mental models are the internal cognitive representations of the world constructed based on life experiences, perceptions, and worldviews (Jones et al. 2011, 2014). Cabrera et al. (2015) contended that wicked problems are a result of the mismatch between an external reality and individuals' perceptions of that reality based on their mental models. However, in a hydro-social context, "communication between people with different views does not necessarily result in one of the communicants changing their mental model" (Abel et al. 1998:86). Existing mental models can be used to filter information, which depending on the fit with current understandings of the world, may be rejected or used to reinforce themselves (Jones et al. 2011). The implication is that culture in hydropolitics can be a blessing where values, communication, and interactions are similar between actors, or a curse when these attributes diverge and/or there are generally negative feelings across cultural boundaries (Dinar 2007). Therefore, it is important to examine collective mental models in hydropolitical contexts, whether considering individual stakeholder groups, regional or national institutions, or multinational based governance/management entities.

Given these fundamental complexities in transboundary cooperation, various types of tools are used in hydropolitical contexts to facilitate dialogue and foster shared understandings, including visual representations of the complex social-ecological systems (SES). Westervelt and Cohen (2012:292) observed that "society has reached the point where the complexity of environmental, interpersonal, and interagency connections is growing faster than the human mind can evolve to comprehend them." Findings from cognitive science and psychology show that humans have overcome these limits to thought, reasoning, and memory, by making use of cognitive artifacts, such as maps, diagrams, etc., that make cognitive processes more effective and may amplify cognition overall (Arias-Hernandez et al. 2012). More importantly for hydropolitical contexts, cognitive science

${ }^{1}$ University of Idaho Water Resources Program, ${ }^{2}$ Portland State University System Science Program, ${ }^{3}$ University of Massachusetts Boston School for the Environment, ${ }^{4}$ University of Victoria Water Innovation and Global Governance (WIGG) Lab, ${ }^{5}$ Austin Peay State University, Department of Communication, ${ }^{6}$ University of Washington Department of Human Centered Design and Engineering, ${ }^{7}$ Michigan State University Department of Community Sustainability, ${ }^{8}$ Michigan State University Department of Philosophy, ${ }^{9}$ Laursen Evaluation \& Design, LLC 
also holds that such socially constructed external mediating devices provide a basis for shared understandings and knowledge, and are necessary for task completion and problem solving in organizational settings (Lorenz 2001). In this manner, these visual devices function as "boundary objects," which enable interaction, dialogue, and translation across groups by being flexible and adaptable, while at the same time conveying more specific meanings (Star and Griesemer 1989). We find this concept helpful in describing the meaning making that is involved in complex negotiation across cultures in international transboundary water agreements.

\section{Systems thinking and DSRP}

Another area of literature that is focused on improving mental models to better match reality to improve collaboration and face wicked problems, is systems thinking (Cabrera and Cabrera 2015). According to Nandalal and Simonovic (2003:2), "complex water resources planning problems heavily rely on systems thinking, which is defined as the ability to generate understanding through engaging in the mental model-based processes of construction, comparison, and resolution." Winz et al. (2009) suggested that a more holistic understanding of system structure is necessary for effective management and understanding of complex systems. Furthermore, systems thinking as an interdisciplinary field of study has been found to effectively serve as a bridge between social and biophysical sciences, influencing existing theories and concepts within many disciplines (Cabrera et al. 2008).

Studying systems thinking or applying a systems thinking framework to a specific context is somewhat difficult, because there exists immense plurality of specialties, methods, and approaches that have developed over time (Cabrera et al. 2015). A framework called DSRP was recently developed that transcends the pluralism by applying a common lexicon that describes the key aspects of systems thinking (Cabrera et al. 2015). According to Cabrera et al. (2015), there are four simple universal cognitive patterns of thinking involved in all systems thinking subfields and methods: distinctions between things/ideas (D); part-whole systems of things/ideas (S); relationships between things/ideas (R); and perspectives of things/ideas (P). The DSRP framework naturally guides one into a process of thinking that is more complex, more robust, more complete, and more systemic; thus these universal patterns correspond to systems thinking (Cabrera and Cabrera 2015). With respect to hydropolitics, the use of DSRP can support intercultural collaboration through the emergence of systems' thinkers that can be more flexible with their mental models, as well as "more ethical, compassionate, self-reflective, and prosocial individuals" (Cabrera et al. 2015:539).

\section{METHODS}

\section{Data selection}

This exploratory study focused on analyzing boundary objects that are part of international transboundary collaboration and are visual representations of information of the type that Eppler and Burkhard (2007) referred to as knowledge maps. More specifically, the 26 such figures that were selected for the analysis were described as problem/solution trees, conceptual models, causal mosaics, etc. Six examples have been provided in Appendix 1. As previously discussed, the literature establishes that visual representations are created through, understood by, and can affect change in mental models of social-ecological systems, and therefore, are important and pertinent tools to be used in hydropolitical contexts.

All of the visuals were part of official documents found on the website of the Executive Management of the Tri-national Commission for the Development of the Pilcomayo River Basin (http://www.pilcomayo.net), which is the multinational entity tasked with the management, by treaty, of the Pilcomayo Basin. The website contains more than 1500 documents related to policy, management, public outreach, reports, etc., that were all reviewed to identify potential visuals that well represented both socialecological information and explicit relationships between the social and ecological phenomena. An iterative process was then used to narrow the selections through triangulation among our research group. The document titles and website locations are provided in a table in Appendix 2.

Of the figures, 21 were part of institutional or social workshop processes, with 15 showing the results of the input from stakeholders, organizations, and institutions as part of consultation processes of the Integrated Management and Master Plan of the Pilcomayo River Basin Project. The remaining boundary objects were included in the Environmental and Socioeconomic Baseline of the Pilcomayo River Basin Report and other documents of the master plan project, as well the 2010 Integrated Management of the Pilcomayo River Master Plan, itself. Thus, every boundary object selected for analysis was part of a participatory process and/or displayed the direct results of engagement with stakeholders, organizations, and institutions in the basin. As such, the figures not only provided rich socialecological relationships and demonstrated most or all aspects of DSRP well, but were also excellent candidates for a content/maptype analysis to elicit mental models in the basin.

\section{Analysis}

A modified version of content/map analysis (Carley and Palmquist 1992, Carley 1993) that integrated the DSRP theory for systems thinking (Cabrera et al. 2015) was used to elicit the mental models of the institutions and participating stakeholders/ organizations involved in the construction of the boundary object visuals. Content/map analysis has successfully been used in previous studies to elicit the mental models of participants related to hydro-social contexts (Abel et al. 1998, Jones et al. 2011, 2014). This research builds on the content/map analysis theory of exploring the concepts and relationships to elicit mental models by also categorizing part-whole systems and perspectives, which can allow for a more complete understanding. In addition, concept/map analysis is typically applied to text and thus relationships can be primarily implicit and/or require a deep understanding of social knowledge (Carley 1993). By focusing on knowledge map-type visuals that explicitly represent relationships (i.e., with arrows), we believe that mental model elicitation may be improved, especially in somewhat unfamiliar contexts or when a more rapid appraisal is necessary. However, to address Carley's (1993) point that also including implicit concepts allows for the comparison of additional shared meanings and social knowledge, we also reviewed the sections in the documents that included, referenced, or were related to the boundary objects. The additional readings also provided clarity to the meanings of the text in the visuals, especially when abbreviated words or phrases 
were used. Given that all documents were written in Spanish, this also ensured that meanings that were lost in translation were reduced.

With the additional elements of DSRP and large number of concepts that were common in these selected visual representations, the types of mapping typically performed in content/map analyses were not sufficient. In addition, given the knowledge map nature of the selected boundary objects, they were already in a suitable format to be compared for structural similarity, thus conversion into an alternative map format was not necessary. Therefore, we used tables to reorganize and compare the distinct concepts, part-whole systems, relationships, and perspectives. The proper approach for different scenarios and applications would be an area for future research.

\section{Pilcomayo River Basin hydropolitical and social-ecological contexts}

Whereas some of the initial agreements in the overall La Plata River Basin were project-based, Argentina, Paraguay, and Bolivia took an integrated sub-basin approach in signing the Pilcomayo River Basin Treaty in 1995, which focuses on water resource issues in the basin through programs and a master plan, and established the Tri-national Pilcomayo Commission (UNEP 2007, del Castillo Laborde 2008). More specifically, the agreement tasked the Tri-national Commission with the following objectives:

- manage the natural resources and economic development of the basin;

- establish a management plan for funding and prioritization;

- conduct studies and monitoring, then prepare reports on hydrological issues/geomorphological issues, environmental quality, and potential engineering strategies, share and publicize data and information basin-wide;

- and, develop pollution prevention and ecological protection programs (Government of Argentina, Government of Brazil, and Government of Paraguay 1995).

In 2000, with the support of the European Union and through the commission, the countries began to collaborate on the Integrated Management and Master Plan for the Pilcomayo River Basin Project, which focused on water quality, quantity, and erosion issues (del Castillo Laborde 2008).

The Pilcomayo River Basin is one of few rivers in South America that has not been regulated by hydrotechnical works, such as dams (Smolders et al. 2002). The natural river system begins in the Andes Mountains in Bolivia and flows from West to East across the Chaco Plains, forms the border between Argentina and Paraguay, and indirectly connects with the Paraguay River in Ascunsción (del Castillo Laborde 2008, Martín-Vide et al. 2014). The small sediment size and the strong impact of the rainfall cycle on river flow have resulted in heavy erosion and subsequent sediment deposits that have blocked the river and created an alluvial fan system in the Chaco Plains (Smolders et al. 2002). The incredible volume of sediment is one of the highest loads in the world (an average of 140 million tons), primarily carried during the short three-month long wet season, which has caused the river to retreat kilometers upstream each year (Martín-Vide et al. 2014). It has been predicted that when the blockage reaches some critical point location, the river will change course completely and no longer serve as the border between Argentina and Paraguay (Smolders et al. 2002). As it is now, the blocked flow already spills across the plains in random patterns that sometimes leaves one of the two countries without water for the population, cattle farming, and declining migratory shad fisheries, which are an important source of income and food for all three countries (Martín-Vide et al. 2014).

Another important aspect of the basin is that Cerro Rico in Potosí, Bolivia has the world's largest silver deposit and intensive mining for silver and many other metals has proceeded for five centuries, resulting in continuous discharges of acid mine drainage (AMD) that continue to have an impact on riparian environments far downstream (Strosnider et al. 2013). In recent years, one of the major sources of discharge has been froth flotation waste and its tailings directly into headwater tributaries (Miller et al. 2004). Even though Bolivia's environmental laws have been getting stronger, non-compliance is widespread and AMD is also released from centuries of waste rock, tailings, ore dumps, mine passages, flooding and dewatering of abandoned mines, etc. (Strosnider et al. 2013). Recently, breaches of tailings dams have resulted in significant fish kills hundreds of kilometers downstream (Hudson-Edwards et al. 2001). Downstream communities have also been impacted, because they use river water for irrigating crops for both subsistence and commercial sale, and the contamination has resulted in metals concentrations in both irrigated soils and crops that have been found to exceed human health guidelines (Miller et al., 2004). The increased concentrations of metals far downstream in the Pilcomayo were measured at several orders of magnitude above natural background levels and have been correlated with fertility and child development deficiencies in riparian indigenous communities (Strosnider et al. 2013).

\section{RESULTS AND DISCUSSION}

\section{Distinctions}

It is necessary in both content/map analyses and DSRP to identify distinct concepts/ideas to see how they are related. To compare across the 26 visuals with many specific individual concepts, it was also important to find similar or overlapping ideas that could be combined to make the next steps in the analysis more manageable. The 17 broader concepts and some additional descriptions, which were found to characterize the visual, are listed below:

- Uncontrolled/unpredicted/unaltered natural phenomena, includes extreme events, variable hydrological behavior, the retreat of the Pilcomayo River, erosion and sediment transport, lifecycle of fish (shad), etc.

- Inter-regional/international coordination/effective basin management, includes integrated basin management

- Knowledge capacity, institutions, resources, or networks

- Regional institutional capacity, prioritization of environmental problems, or enforcement

- Legal, policy, or regulatory frameworks

- Infrastructure for managing natural phenomena/controlled natural phenomena, includes constructed hydrological infrastructure (dams, canals, etc.) 
- Infrastructure/processes for pollution discharge control and/or remediation

- Overuse, accidental, noncompliant, or unregulated release of environmental contaminants

- Agriculture, livestock, forestry, fishing, and hunting practices, includes absence of poaching

- Sustainable use of water/exploitation of natural resources

- Habitat/biodiversity, includes deforestation and fragmentation

- Surface water, sediment, soils, and/or crop quality, includes absence of desertification, salinization, or contamination

- Distribution of wealth/lack of impoverishment/quality of life

- Social connectedness/Lack of migration, uprooting, and displacement/maintenance of cultural and traditional practices

- Human health, life expectancy, environment, livelihoods, and food security

- Availability of water, soils, and land/resource sufficient for consumption and preservation of the environment

- Physical impacts/damage to population, economic activities, infrastructure, and/or equipment from natural phenomena, includes physical loss of productive soil from erosion, etc.

It is interesting to note that the development of these knowledge maps included natural phenomena, institutional infrastructure, human process, ecological health, and social welfare-type concepts, which harkens back to the more integrated treaty approach and management plan project, as well as the inclusiveness of the participatory processes that occurred as part of their creation. One important point is that the documents did have discussions of unique impacts to indigenous communities and their needs, but those specific concepts were not referenced in the boundary objects themselves. Thus, all of the social welfaretype ideas were broader, but they definitely put a strong focus on rural communities, more generally.

\section{Systems (part-whole)}

This second part of DSRP, exploring how concepts are lumped together in part-whole systems, is not considered in traditional content/map analysis. Given that these were visual boundary objects, it was not difficult to identify how concepts were explicitly grouped, because they were combined by using colors, larger boxes, etc. Applying our method to solely text formats would be more difficult and would require a much more in-depth understanding of the context and social knowledge. However, as can be seen in the list below, not much insight was gained by using solely the explicit groupings provided in the figures. Thus, it was not considered valuable to display all of the parts for each whole here, but they can be easily identified in the original figures (for examples see Appendix 1). Also, 11 of the figures either did not include any part-whole structures, or only some of the concepts were grouped in this manner. More generally, we hypothesize that it would be more interesting for eliciting mental models from these types of visuals, to attempt to also identify implicit part-whole structures that can be understood by looking at the text and ideas themselves. To some degree, we performed this action by combining ideas as discussed in the distinctions section above. However, a more meaningful approach for this portion of the content-DSRP mental model elicitation would likely require a much deeper reading of the documents that contain the boundary objects and understanding of the overall context, which did not occur as part of this exploratory study. Such an investigation would also support better understanding of distinct concepts that are already wholes of parts themselves. For instance, ideas such as deforestation and biodiversity may be incorporating different meanings for different regions, i.e., they could be describing both native and non-native vegetation, etc.

- Cause, problem, and effect: seven visuals

- Action, objective, and outcome: one visual

- Agricultural frontier expansion and environmental degradation: one visual

- Natural factor, biological components, and anthropogenic components: one visual

- Principal actors and deterioration of the quality of life of the inhabitants: three visuals

- Environmental problem indicator, external stress factors and inherent basin conditions, anthropogenic intervention, and processes of environmental degradation: one visual

\section{Perspectives}

The next element of DSRP that we applied, examining the perspectives represented in the figures, is also not normally considered when applying content/map analysis. It is important to note that when applying DSRP in a general sense, it may be useful to consider the many perspectives that can be taken both within a boundary object and/or external to it (i.e., farmers, fishermen, policymakers, etc.). For the purposes of this study, only the primary perspective or main idea that was represented in each knowledge map was used. Given the sources and uses of these particular boundary objects, it was reasonable to assume that the primary external perspective is the synthesized group of institutions, stakeholders, and organizations that participated in the development of the documents (including workshops and consultation processes as previously discussed). However, when this process is applied in other contexts, such assumptions would not necessarily be appropriate and additional investigation or analysis regarding external perspectives would provide more meaningful mental model elicitations. As can be seen in the list below of all perspectives in the visuals, we find that considering perspectives definitely provides some additional useful insight into what the priorities, foci, and issues were driving these discussions and processes. Again, as discussed in the academic literature, the biophysical issues (i.e., erosion and river retreat) and environmental degradation/contamination were high priorities. We also again found that the main focus of several of the boundary objects were related to integrated management. It is interesting to see that eight of the figures were mainly interested in quality of life issues, which again demonstrates the participatory design/nature of the processes. One important additional finding here is that although economic development was represented in the overall concepts, with respect to perspectives, it was not a main focus. 
- Retreat of the river

- Retreat and digression of Pilcomayo River

- Physical impacts to population, activities, infrastructure, and equipment due to natural phenomena

- Intense processes of erosion and sedimentation

- Environmental degradation due to water pollution

- Degradation by mining and hydrocarbon environmental liabilities

- Environmental degradation processes

- Habitat and biodiversity loss

- Salinization

- Desertification

- Habitat Loss

- Loss of regional biodiversity

- Distinct processes of degradation of terrestrial ecosystems in the Pilcomayo Basin

- Development of different stages of the biological cycle of shad with natural and anthropogenic factors

- Loss of habitat, biodiversity, and desertification

- Integrated water resource management

- Integrated causal relationships of problems and indicators in the Pilcomayo River Basin

- Integrated objectives and most significant relationships in the Pilcomayo Basin

- Deterioration of the quality of life of the inhabitants (two figures)

- Low quality of life/extreme poverty (three figures)

- Improved quality of life/reduced poverty (three figures)

\section{Relationships}

The other key component that connects content/map analysis and DSRP is relationships between concepts/ideas. The relationships in the 26 visuals were generally described as cause-effect, causal, and actor-result, with only a few lacking a description and no other relationship types. Directionality of the relationships (arrows) were provided in all cases. Signs indicating positive or negative relationships were not provided. However, the language of the concepts (i.e., deficient, improved, impacted, etc.), along with the relationship descriptions served as a sufficient indication of the sign. Relationship strength was only provided in one of the visuals and was thus not considered in the analysis. As with the part-whole systems, it may also be possible in some cases to do further analysis of the document text to glean more understanding related to the strength of the relationships, but it was not our experience in this case. Similarly, additional information related to the relationship types (such as, caused when?, how?, etc.) was not sufficiently demonstrated in the document text for the majority of the figures.

Appendix 3 provides a table that demonstrates the frequency of representations of the relationships between each distinct concept/idea (as described above) for the 26 knowledge maps. The table also displays an indication of whether the idea was represented exactly as written above, or the opposite (i.e., deficient institutional capacity, decreased biodiversity, or decreased environmental discharges, etc.), which also provides an understanding of the directionality of the relationships. In a few cases the relationship represented an increase to a concept that was already positive (i.e., improved sustainable use), but we felt that simply considering the positive representation (i.e., sustainable use) was sufficient for the purposes of this study. The results of the relationships could be further analyzed and discussed in many ways, but we felt that it would be appropriate to simply discuss some main findings and interesting points related to the mental models for the purposes of this exploratory research.

Two of the distinct ideas were related to other ideas at a high frequency. One of these concept categories was "uncontrolled/ unpredicted/unaltered natural phenomena," which was repeatedly shown to have an effect on other natural phenomena, institutions, ecological health, and social welfare-type concepts. In this case, most of the relationships of uncontrolled phenomena to other natural phenomena were represented as direct (i.e., natural flood cycles transporting sediment). However, a mix of direct and inverse relationships were represented with respect to ecological health-type concepts, which demonstrates the acknowledgement of the complexity in ecological systems and how humans socially construct ideas of desirable conditions. The relationships of uncontrolled phenomena to institution-type concepts were all inverse and were primarily focused on interregional coordination/effective basin management. The impacts to social welfare-type concepts were also primarily inverse, as expected, but six were direct and represent the fact that control mechanisms can provide resources for some, while reducing access for others.

The second distinct idea with high frequency for relationships in several group categories was "surface water, sediment, soils, and/ or crop quality." The relationships with institutions were positive and were represented as cause-effect in the figures, specifically focused on inter-regional coordination and knowledge capacity. Those specific connections were not well explained in the text and perhaps were meant to represent an indicator as opposed to a cause. As expected, this concept category had all direct relationships with human process-type concepts, represented by agriculture, forestry, etc. and sustainable use. The relationships were also all direct with respect to ecological health-type concepts, such as habitat/biodiversity. Finally, five of the six social welfaretype concepts were represented as being related directly to this distinct concept, which demonstrates a broad focus on the importance of sediment, soils, and crop quality for the institutions and stakeholders in the Pilcomayo Basin.

"Economic productivity/development" was found to have a moderate or high frequency in relationships. The relationships with institution-type concepts were direct and were focused on knowledge capacity, which represents the need for economic resources for training, monitoring, etc. The relationships with human process-type concepts were also direct, which is as expected for agriculture, forestry, etc., but the direct cause-effect relationships with sustainable use/exploitation provides an 
interesting point of discussion. Similar to sustainable use, the relationships with ecological health-type concepts were more complex because there are direct relationships to surface water quality, etc., but the figures also indicated that mining development can cause degradation of environmental quality. The relationships of economic productivity were almost all direct with social welfare-type concepts, including wealth and human health, etc., with one outlier that indicated that mining development has a negative effect on the distribution of wealth.

The "agriculture, livestock, forestry, fishing, and hunting practices" distinct idea also had moderate and a few high frequency results. Similar to the surface water concept, the direct relationships with inter-regional coordination were not well explained. The relationships with human process-type concepts, including other aspects of the same category and sustainable use were all direct, except one case in which neutral/good cattle ranching practices were related to the poor practice of exceeding the carrying capacity. The 24 relationships of this concept category with ecological health-type concepts were split between direct and inverse, and were almost all negative-negative or positive-negative, indicating that both neutral/good and poor practices can affect habitat/biodiversity and environmental quality.

\section{CONCLUSIONS}

The purpose of this exploratory study was to test a new framework for eliciting mental models from visual boundary objects using content/map analysis concepts combined with the DSRP framework in a hydropolitical context. We found that overall, the process was successful for gaining insights from individual knowledge map visuals, as well as for comparing many such boundary objects for eliciting overall shared mental models in an international transboundary river basin. Furthermore, we found that the addition of the perspectives aspect of DSRP is not only meaningful, but enhances the understanding of mental models in this context. The part-whole systems aspect of DSRP also added an interesting component, but the proper application procedure needs to be further developed for this particular approach, depending on whether explicit or implicit use is desired. The depth of this analysis was sufficient for proof of concept, however the next step for a deeper understanding of mental models would be to do cross-comparing of the different elements of DSRP, such as examining relationships for similar perspectives, etc. The Cabrera Research Lab at Cornell University has developed an online software called Plectica (www.plectica.com) that helps facilitate this type of advanced DSRP analysis and would be useful for further research.

Though our intent was to test this method for visual boundary objects that could more rapidly be analyzed and compared than text, we believe that this method could also be used for more indepth document analysis for mental model elicitation. The method could also potentially be used for other types of static or even dynamic visuals, but further research would be needed to investigate those applications. Though we purposefully chose the hydropolitical context because of the higher importance of boundary objects and higher likelihood of use, we also feel that this method would generally be meaningful in other natural resource contexts and at smaller scales, especially where conflict and/or collaboration is already apparent or expected in the future.
Responses to this article can be read online at: http://www.ecologyandsociety.org/issues/responses. php/10586

\section{Acknowledgments:}

This work was supported by the National Socio-Environmental Synthesis Center (SESYNC) under funding received from the National Science Foundation DBI-1052875. We would like to acknowledge the valuable counsel of our external experts on the project, Barbara Cosens of the University of Idaho College of Law and Derek Cabrera at Cornell University and his colleagues at the U.S. Department of Agriculture's ThinkWater program.

\section{LITERATURE CITED}

Abel, N., H. Ross, and P. Walker. 1998. Mental models in rangeland research, communication and management. Rangeland Journal 20:77-91. https://doi.org/10.1071/RJ9980077

Ackoff, R. L. 1979. The future of operational research is past. Journal of the Operational Research Society 30:93-104. https://doi. org/10.1057/jors.1979.22

Arias-Hernandez, R., T. M. Green, and B. Fisher. 2012. From cognitive amplifiers to cognitive prostheses: understandings of the material basis of cognition in visual analytics. Interdisciplinary Science Reviews 37:4-18. https://doi.org/10.1179/0308018812Z.0$\underline{000000001}$

Blatter, J., H. M. Ingram, and P. M. Doughman. 2001. Emerging approaches to comprehend changing global contexts. Pages 3-30 in J. Blatter and H. M. Ingram, editors. Reflections on water: new approaches to transboundary conflicts and cooperation. MIT Press, Cambridge, Massachusetts, USA. https://doi.org/10.7551/ mitpress/5844.003.0006

Cabrera, D., and L. Cabrera. 2015. Systems thinking made simple: new hope for solving wicked problems. Odyssean, Ithaca, New York, New York, USA.

Cabrera, D., L. Cabrera, and E. Powers. 2015. A unifying theory of systems thinking with psychosocial applications. Systems Research and Behavioral Science 32:534-545. https://doi. org/10.1002/sres.2351

Cabrera, D., L. Colosi, and C. Lobdell. 2008. Systems thinking. Evaluation and Program Planning 31:299-310. https://doi. org/10.1016/j.evalprogplan.2007.12.001

Carley, K. 1993. Coding choices for textual analysis: a comparison of content analysis and map analysis. Sociological Methodology 23:75-126. https://doi.org/10.2307/271007

Carley, K., and M. Palmquist. 1992. Extracting, representing, and analyzing mental models. Social Forces 70:601-636. https://doi. org/10.1093/sf/70.3.601

Dawes, S. S., A. M. Cresswell, and T. A. Pardo. 2009. From "need to know" to "need to share": tangled problems, information boundaries, and the building of public sector knowledge networks. Public Administration Review 69:392-402. https://doi. org/10.1111/j.1540-6210.2009.01987_2.X 
del Castillo Laborde, L. 2008. The Rio de la Plata River Basin: the path towards basin institutions. Pages 269-292 in O. Varis, C. Tortajada, and A. K. Biswas, editors. Management of transboundary rivers and lakes. Springer, Berlin, Germany. https:// doi.org/10.1007/978-3-540-74928-8 11

Dinar, S. 2007. International water treaties: negotiation and cooperation along transboundary rivers. Routledge, New York, New York, USA. https://doi.org/10.4324/9780203934456

Eppler, M. J., and R. A. Burkhard. 2007. Visual representations in knowledge management: framework and cases. Journal of Knowledge Management 11:112-122. https://doi.org/10.1108/13$\underline{673270710762756}$

Faure, G. O., and G. Sjostedt. 1993. Introduction. Pages 1-16 in G. O. Faure, and J. Z. Rubin, editors. Culture and negotiation: the resolution of water disputes. Sage, Newbury Park, London, England.

Government of Argentina, Government of Brazil, and Government of Paraguay. 1995. Agreement establishing the Trinational Commission for the Development of the Pilcomayo River Basin. Government of Argentina, Government of Brazil, and Government of Paraguay, La Paz, Bolivia. [online] URL: https:// www.internationalwaterlaw.org/documents/regionaldocs/ Pilcomayo Acuerdo Constitutivo.pdf

Hudson-Edwards, K. A., M. G. Macklin, J. R. Miller, and P. J. Lechler. 2001. Sources, distribution and storage of heavy metals in the Río Pilcomayo, Bolivia. Journal of Geochemical Exploration 72:229-250. https://doi.org/10.1016/S0375-6742(01)00164-9

Jensen, S., and A. Kushniruk. 2016. Boundary objects in clinical simulation and design of eHealth. Health Informatics Journal 22:248-264. https://doi.org/10.1177/1460458214551846

Jones, N. A., H. Ross, T. Lynam, P. Perez, and A. Leitch. 2011. Mental models: an interdisciplinary synthesis of theory and methods. Ecology and Society 16(1):46. https://doi.org/10.5751/ ES-03802-160146

Jones, N. A., H. Ross, T. Lynam, and P. Perez. 2014. Eliciting mental models: a comparison of interview procedures in the context of natural resource management. Ecology and Society 19 (1):13. https://doi.org/10.5751/ES-06248-190113

Lorenz, E. 2001. Models of cognition, the contextualisation of knowledge and organisational theory. Journal of Management and Governance 5:307-330. https://doi.org/10.1023/A:1014098928477

Martín-Vide, J. P., M. Amarilla, and F. J. Zárate. 2014. Collapse of the Pilcomayo River. Geomorphology 205:155-163. https://doi. org/10.1016/j.geomorph.2012.12.007

Miller, J. R., K. A. Hudson-Edwards, P. J. Lechler, D. Preston, and M. G. Macklin. 2004. Heavy metal contamination of water, soil and produce within riverine communities of the Río Pilcomayo basin, Bolivia. Science of the Total Environment 320:189-209. https://doi.org/10.1016/j.scitotenv.2003.08.011

Nandalal, K. D. W., and S. P. Simonovic. 2003. Resolving conflicts in water sharing: a systemic approach. Water Resources Research 39:1-11. https://doi.org/10.1029/2003WR002172
Rittel, H., and M. Webber. 1973. Dilemmas in a general theory of planning. Policy Sciences 4:155-169. https://doi.org/10.1007/ BF01405730

Rothman, J. 1995. Pre-negotiation in water disputes: where culture is core. Cultural Survival Quarterly 19:19-22. [online] URL: https://www.culturalsurvival.org/publications/cultural-survivalquarterly/pre-negotiation-water-disputes-where-culture-core

Smolders, A. J. P., G. Hiza, G. Van der Velde, and J. G. M. Roelofs. 2002. Dynamics of discharge, sediment transport, heavy metal pollution and sábalo (Prochilodus lineatus) catches in the Lower Pilcomayo River (Bolivia). River Research and Applications 18:415-427. https://doi.org/10.1002/rra.690

Star, S. L., and J. R. Griesemer. 1989. Institutional ecology, 'translations' and boundary objects: amateurs and professionals in Berkeley's Museum of Vertebrate Zoology, 1907-39. Social Studies of Science 19:387-420. https://doi.org/10.1177/03063128$\underline{9019003001}$

Strosnider, W. H. J., F. S. L. López, J. A. LaBar, K. J. Palmer, and R. W. Nairn. 2014. Unabated acid mine drainage from Cerro Rico de Potosí, Bolivia: uncommon constituents of concern impact the Rio Pilcomayo headwaters. Environmental Earth Sciences 71:3223-3234. https://doi.org/10.1007/s12665-013-2734-z

Turton, A., and R. Henwood, editors. 2002. Hydropolitics in the developing world: a Southern African perspective. University of Pretoria, Pretoria, South Africa.

United Nations Environment Programme (UNEP). 2007. Hydropolitical vulnerability and resilience along international waters: Latin America and the Caribbean. United Nations Environment Programme, Nairobi, Kenya. [online] URL: http:// wedocs.unep.org/bitstream/handle/20.500.11822/7803/-Hydropolitical $\%$ 20Vulnerability $\% 20$ and $\% 20$ Resilience $\% 20$ Along $\% 20$ International $\%$ 20Waters $\% 20 \% 20$ Latin $\% 20$ America $\% 20$ and $\% 20$ the $\%$

20Caribbean-2008858.pdf? sequence $=4 \&$ is Allowed $=\mathrm{y}$

Westervelt, J. D., and G. L. Cohen. 2012. Ecologist-developed spatially-explicit dynamic landscape models. Springer Science and Business, Boston, Massachusetts, USA. https://doi. org/10.1007/978-1-4614-1257-1

Winz, I., G. Brierley, and S. Trowsdale. 2009. The use of system dynamics simulation in water resources management. Water Resources Management 23:1301-1323. https://doi.org/10.1007/ $\underline{\text { s11269-008-9328-7 }}$ 
Fig. A1.1

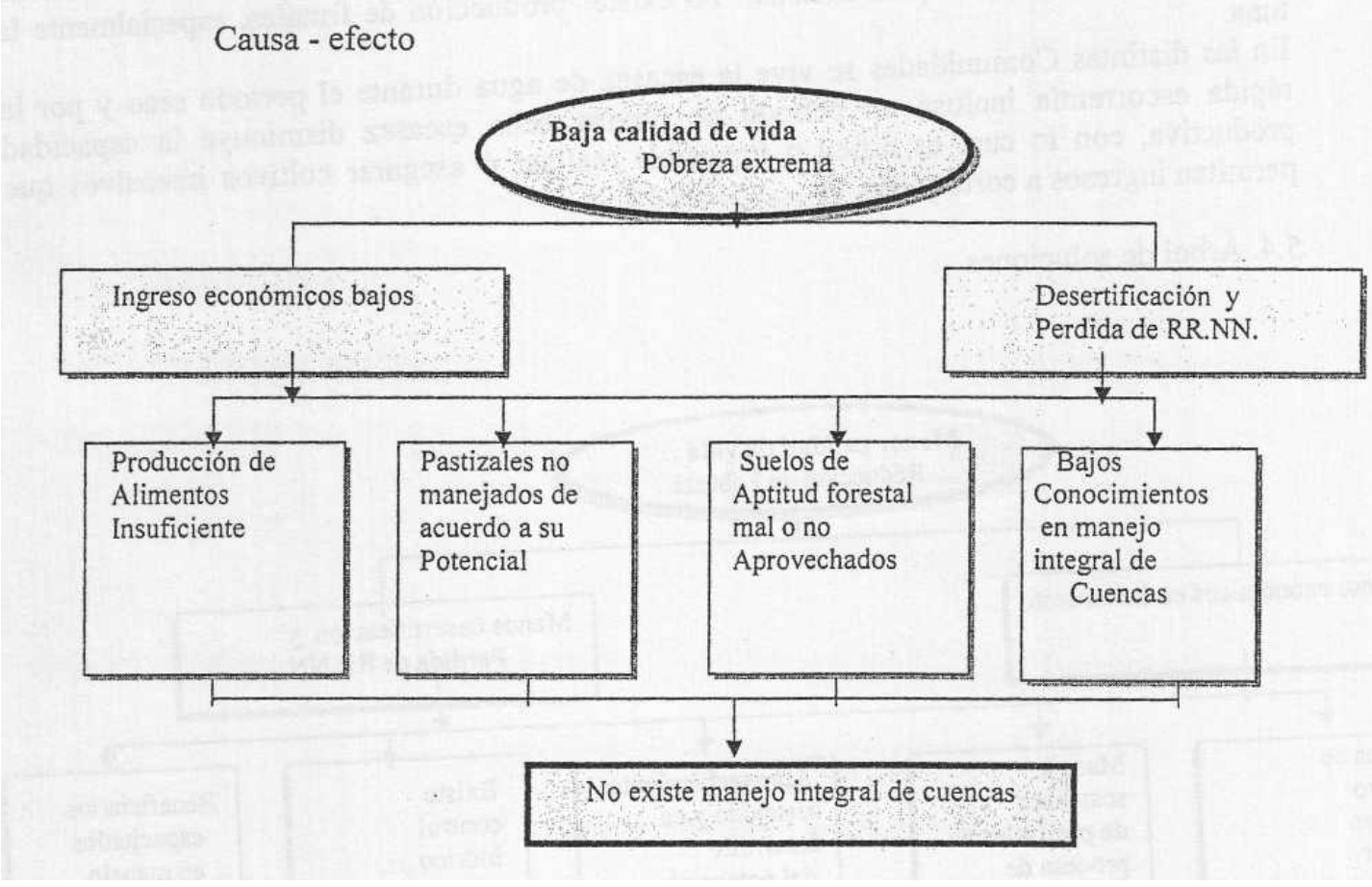

\begin{tabular}{|c|l|}
\hline$\#$ & \multicolumn{1}{|c|}{ Translations from Figure A1.1 } \\
\hline 1 & Cause-effect \\
\hline 2 & Low quality of life/Exteme poverty \\
\hline 3 & Low economic incomes \\
\hline 4 & Desertification and loss of natural resources \\
\hline 5 & Insufficient food production \\
\hline 6 & Pastures not managed in accordance with to their potential \\
\hline 7 & Poorly used or unused soils suitable for forest plantations \\
\hline 8 & Poor understanding/knowledge of Integrated Watershed Management \\
\hline 9 & Integrated Watershed Management doesn't exist \\
\hline
\end{tabular}


Fig. A1.2

\section{GRUPO TEMÁTICO A \\ DENOMINACIÓN: Recursos Hidricos \\ PROBLEMÁTICA: Afectación física de la población, actividades, infraestructura y equipamiento por eventos naturales}

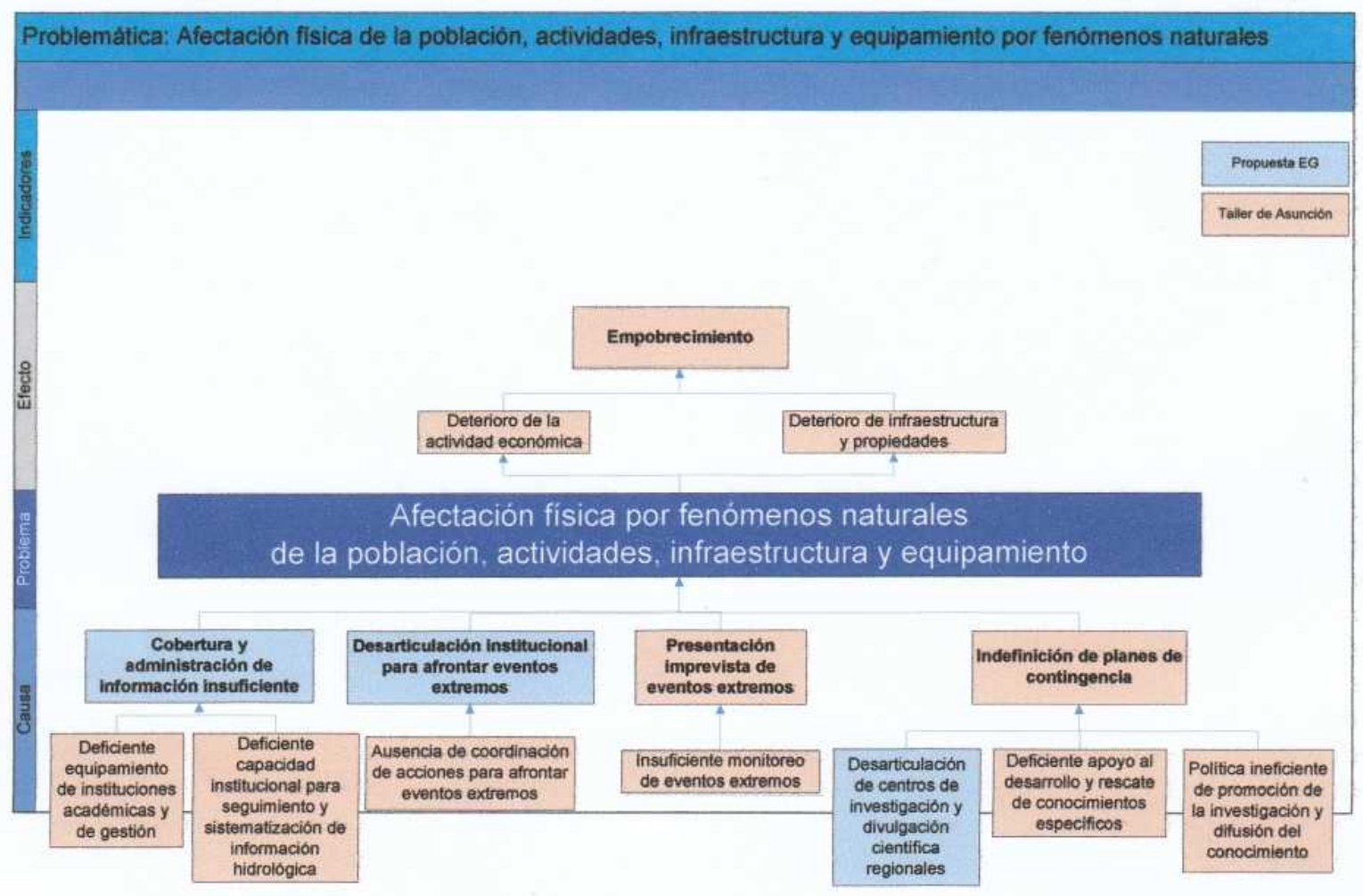

\begin{tabular}{|c|l|}
\hline$\#$ & \multicolumn{1}{|c|}{ Translations from Figure A1.2 } \\
\hline 1 & Problems: Physical impacts to population, activities, infrastructure and equipment due to natural phenomena \\
\hline 2 & EG proposal \\
\hline 3 & Asunción workshop \\
\hline 4 & Cause \\
\hline 5 & Problem \\
\hline 6 & Effect \\
\hline 7 & Indicators \\
\hline 8 & Poorly equipped academic institutions and management \\
\hline 9 & Poor institutional capacity to monitor and systematize hydrological information \\
\hline 10 & Absence of coordination of actions to face extreme events \\
\hline 11 & Insufficient monitoring of extreme events \\
\hline 12 & Disjointed regional scientific research and dissemination centers \\
\hline 13 & Poor support for the development and collection of specific knowledge \\
\hline 14 & Inefficient policy to promote research and dissemination of knowledge \\
\hline 15 & Insufficient information coverage and management \\
\hline 16 & Disjointed institutional coordination to cope with extreme events \\
\hline 17 & Extreme events not predicted \\
\hline 18 & Contingency plans not defined \\
\hline 19 & Physical impacts to population, activities, infrastructure and equipment due to natural phenomena \\
\hline 20 & Impairment of economic activity \\
\hline 21 & Deterioration of infrastructure and properties \\
\hline 22 & Impoverishment \\
\hline
\end{tabular}

Caption Above: "THEMATIC GROUP A / DENOMINATION: Water Resources / PROBLEMS: Physical impacts to population, activities, infrastructure and equipment due to natural events" 
Fig. A1.3

Figura 1-1. Modelo conceptual de relaciones entre el desarrollo de diferentes etapas del ciclo biológico del sábalo con factores de origen natural y antrópico. Los cuadros en verde indican los componentes bióticos, los cuadros violetas representan el componente antrópico

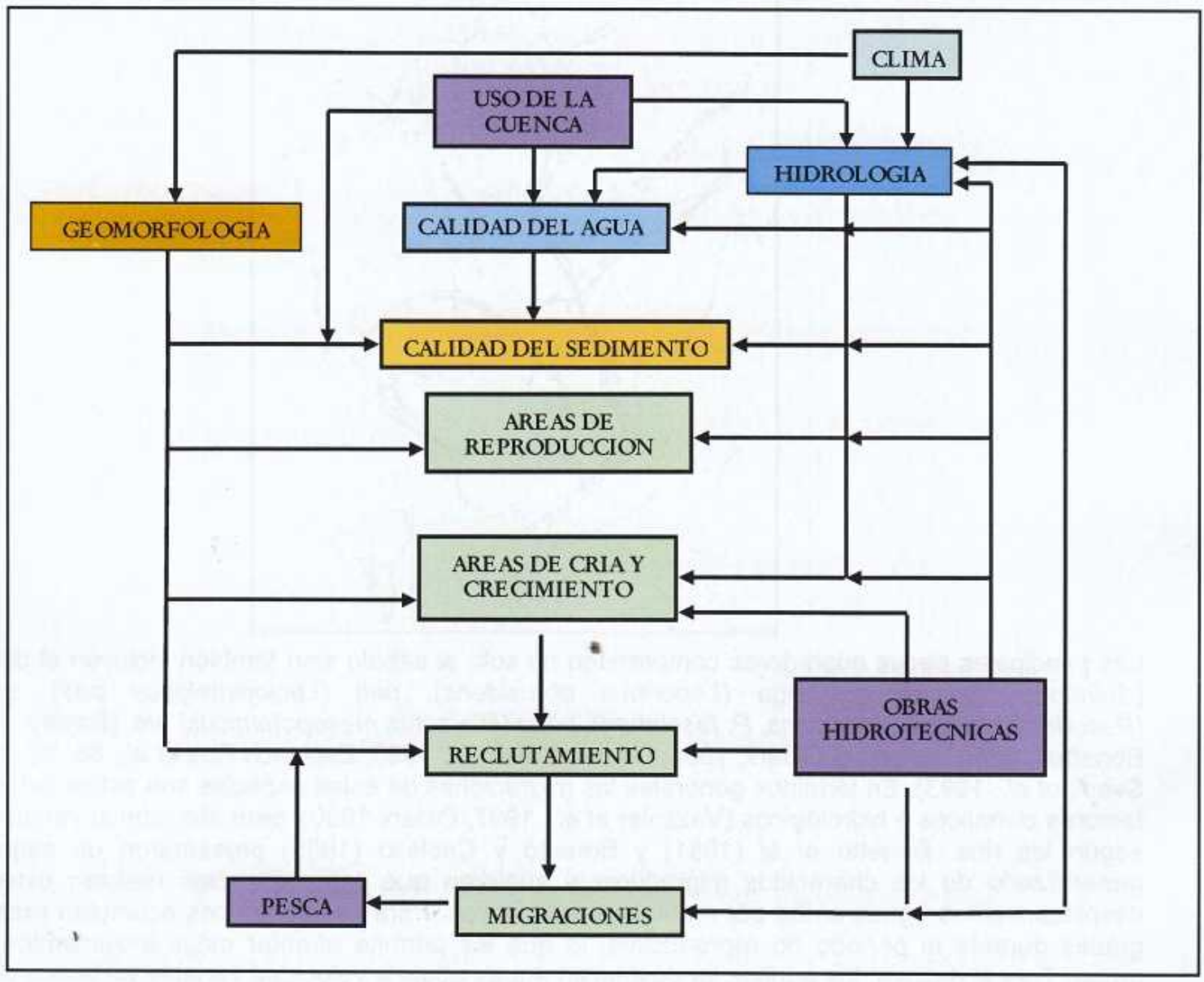

\begin{tabular}{|c|l|}
\hline$\#$ & Translations from Figure A1.3 \\
\hline 1 & Climate \\
\hline 2 & Geomorphology \\
\hline 3 & Use of the basin \\
\hline 4 & Hydrology \\
\hline 5 & Water quality \\
\hline 6 & Sediment quality \\
\hline 7 & Reproduction areas \\
\hline 8 & Growth And brooding areas \\
\hline 9 & Recruitment \\
\hline 10 & Hydrotechnical works \\
\hline 11 & Fishing \\
\hline 12 & Migrations \\
\hline
\end{tabular}

Caption Above: "Figure 1-1. Conceptual Model of relations between the development of different stages of the biological cycle of shad with factors of natural and anthropogenic origin. The squares in green indicate the biotic components, the violet squares represent the anthropogenic components." 
Fig. A1.4

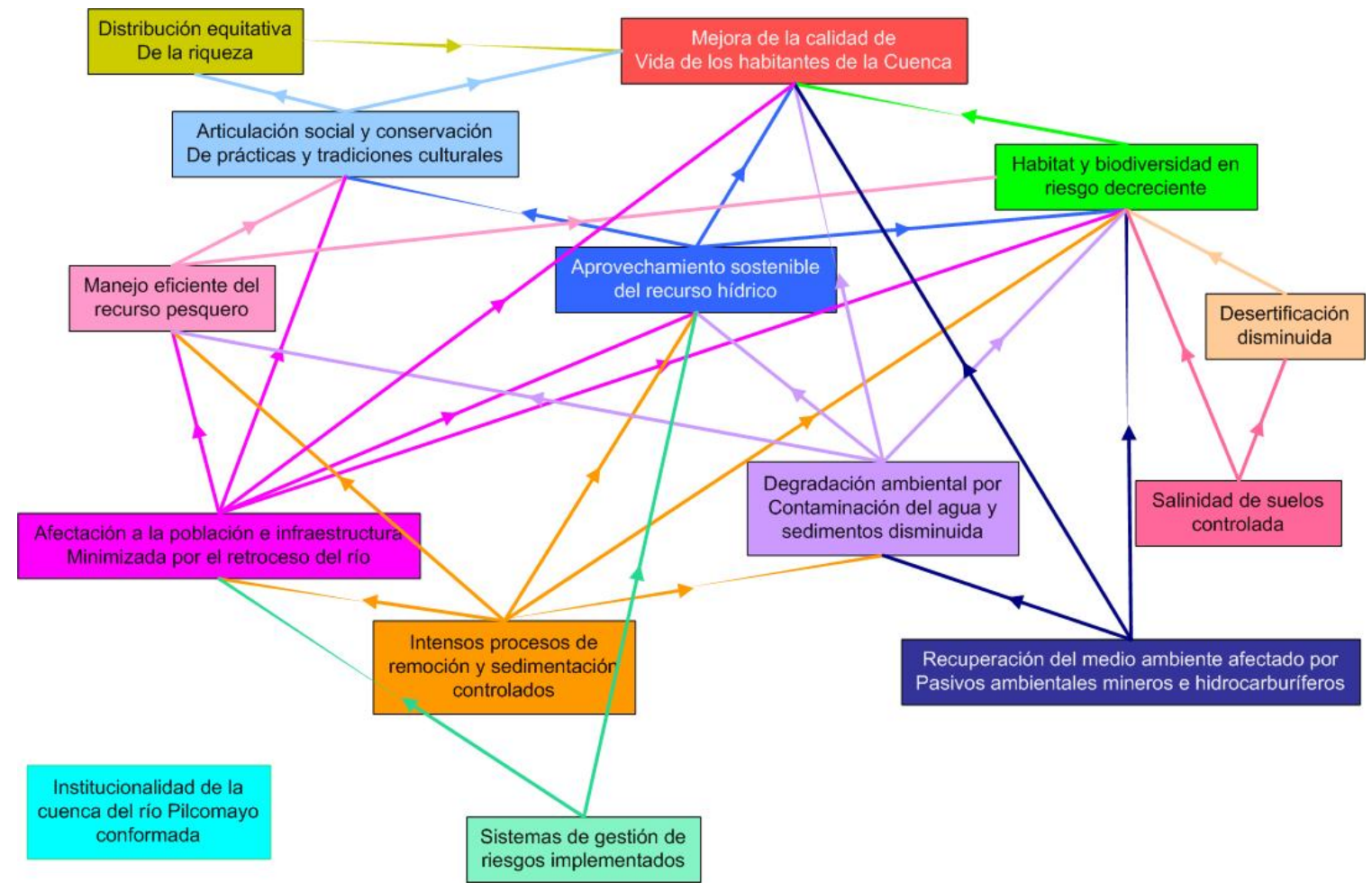

Figura $N^{\circ}$ 6: Esquema árbol integrado de objetivos. Proyecto Pilcomayo.

\begin{tabular}{|c|l|}
\hline$\#$ & \multicolumn{1}{|c|}{ Translations from Figure A1.4 } \\
\hline 1 & Equitable distribution of wealth \\
\hline 2 & Social connectedness and conservation of cultural practices and traditions \\
\hline 3 & Quality of life improvement for inhabitants of Basin \\
\hline 4 & Decreasing risk to habitat and biodiversity \\
\hline 5 & Sustainable use of the water resource \\
\hline 6 & Efficient management of fisheries resources \\
\hline 7 & Decreased desertification \\
\hline 8 & Minimized impacts to population and infrastructure from river retreat \\
\hline 9 & Environmental degradation from water contamination and decreased sediments \\
\hline 10 & Controlled salinization of soils \\
\hline 11 & Control of intense removal and sedimentation processes \\
\hline 12 & Recovery of environment affected by mining and hydrocarbon environmental liabilites \\
\hline 13 & Implemented systems of risk management \\
\hline 14 & Establishmed institutionality of the Pilcomayo River Basin \\
\hline
\end{tabular}

Caption Below: "Figure No. 6: Integrated tree outline of objectives. Project Pilcomayo" 
Fig A1.5

\section{Deterioro de la calidad de vida de los habitantes: El gráfico indica interrelaciones de problemáticas con este fenómeno.}

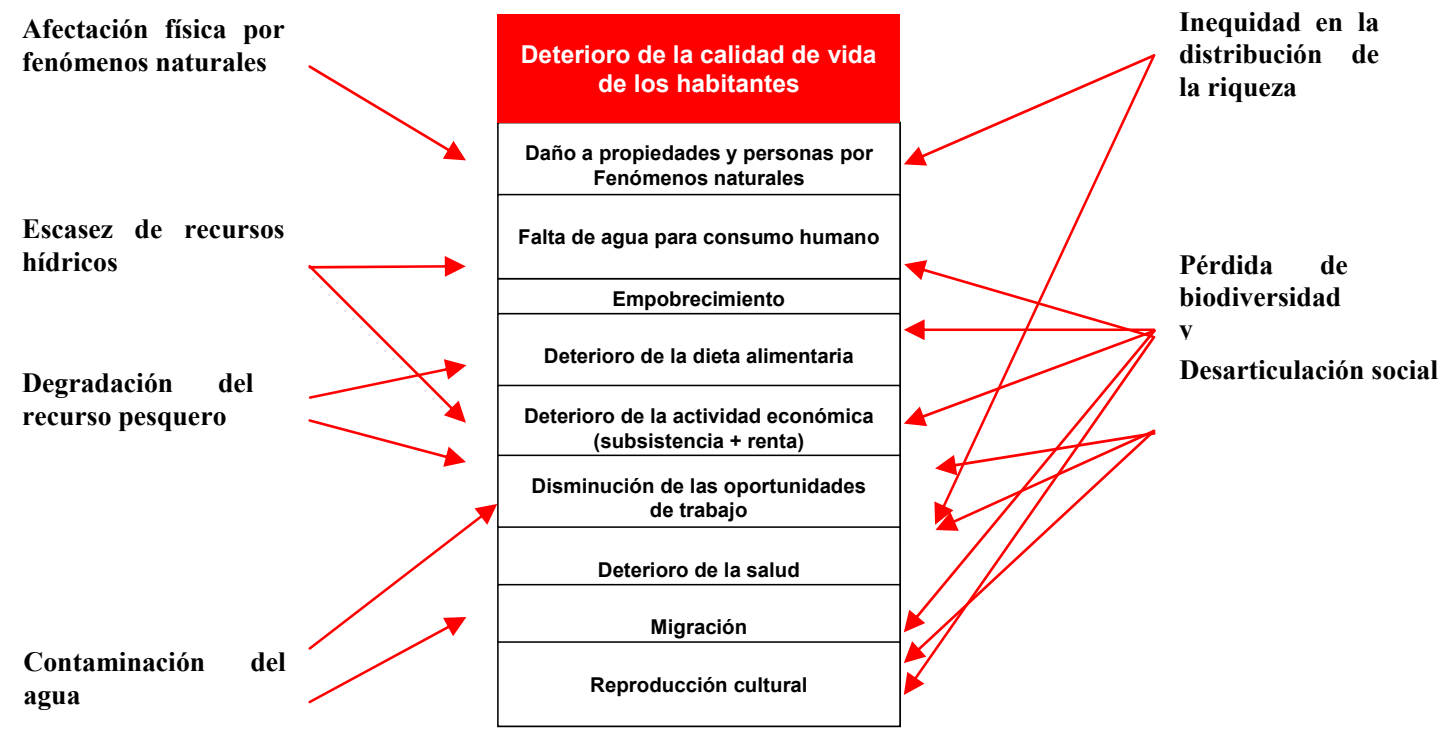

\begin{tabular}{|c|l|}
\hline$\#$ & \multicolumn{1}{|c|}{ Translations from Figure A1.5 } \\
\hline 1 & Physical effects from natural phemomena \\
\hline 2 & Scarcity of water resources \\
\hline 3 & Degradation of fishing resources \\
\hline 4 & Contamination of water \\
\hline 5 & Inequity in the distribution of wealth \\
\hline 6 & Loss of biodiversity and social disconnectedness \\
\hline 7 & Deterioration of the quality of life of the inhabitants \\
\hline 8 & Damage to properties and persons from natural phenomena \\
\hline 9 & Lack of water for human consumption \\
\hline 10 & Impoverishment \\
\hline 11 & Deterioration of food diet \\
\hline 12 & Deterioration of economic activity (subsistence and income) \\
\hline 13 & Decline in employment opportunities \\
\hline 14 & Deterioration of health \\
\hline 15 & Migration \\
\hline 16 & Cultural reproduction \\
\hline
\end{tabular}

Caption Above: "Deterioration of the quality of life of the inhabitants: The graphic indicates interrelationships of problems with this phenomena" 
Fig A1.6

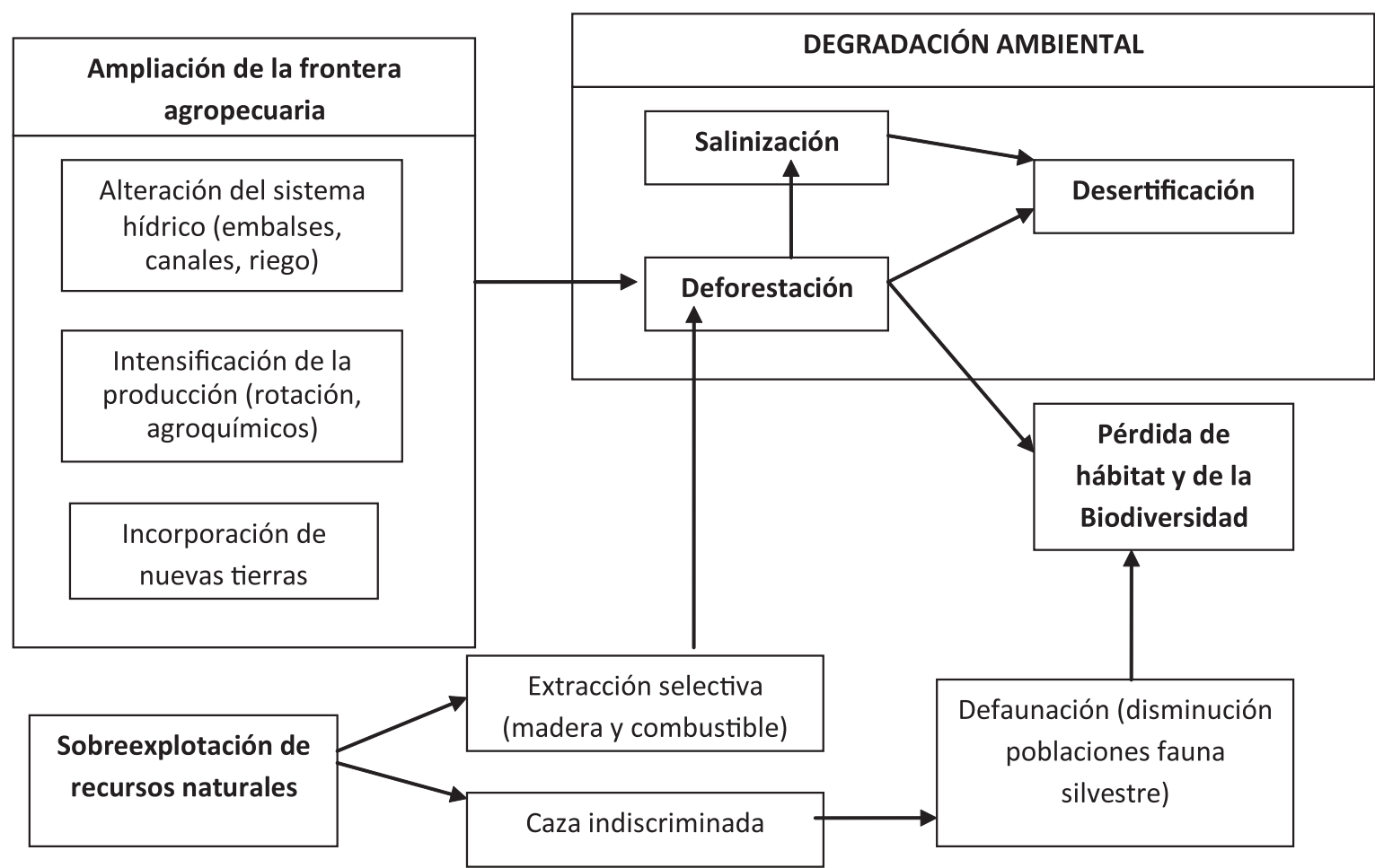

Figura 4.6 1 Relaciones causa-efecto entre los distintos procesos de degradación en los ecosistemas terrestres de la cuenca del río Pilcomayo (ver texto)

\begin{tabular}{|c|l|}
\hline$\#$ & \multicolumn{1}{|c|}{ Translations from Figure A1.6 } \\
\hline 1 & Agricultural frontier expansion \\
\hline 2 & Alteration of the water system (reservoirs, canals, irrigation) \\
\hline 3 & Intensification of production (rotation, agrochemicals) \\
\hline 4 & Incorporation of new lands \\
\hline 5 & Environmental Degadation \\
\hline 6 & Salinization \\
\hline 7 & Deforestation \\
\hline 8 & Desertification \\
\hline 9 & Habitat and Biodiversity loss \\
\hline 10 & Overexploitation of natural resources \\
\hline 11 & Selective extraction (wood and fuel) \\
\hline 12 & Poaching \\
\hline 13 & Loss of fauna (decline in wild fauna populations) \\
\hline
\end{tabular}

Caption Below: "Figure 4.61 Cause-effect relations between distinct processes of degradation in terrestrial ecosystems of the Pilcomayo River Basin (see text)" 


\begin{tabular}{|c|c|c|c|c|}
\hline Document Name & Year & Original Website Location & File Name & Translation \\
\hline $\begin{array}{l}\text { Estudio de la Base Ambiental y Socioeconómica de la Cuenca del rio } \\
\text { Pilcomayo- Informe de Avance -año } 2006\end{array}$ & 2006 & http://www.pilcomayo.net/media/uploads/biblioteca/libro_864_MA-233.pdf & libro_864_MA-233.pdf & $\begin{array}{l}\begin{array}{l}\text { Environmental and Socioeconomic Baseline Study of the Pilcomayo River } \\
\text { Basin- Progress Report -year } 2006\end{array} \\
\end{array}$ \\
\hline $\begin{array}{l}\text { Estudio de la Migración del Sábalo en la Cuenca del río Pilcomayo- Infome } \\
\text { Final - año } 2006\end{array}$ & 2006 & http://www.pilcomayo.net/media/uploads/biblioteca/libro_884_MA-253.pdf & libro_884_MA-253.pdf & $\begin{array}{l}\text { Study of the migration of the Shad in the basin of the Pilcomayo River - } \\
\text { Final Report - year } 2006\end{array}$ \\
\hline $\begin{array}{l}\text { Proyecto Manejo Integral de la Cuenca del río Iturata en el municipio de } \\
\text { Sacaca Fasel - Fase I - año 2006-Bolivia }\end{array}$ & 2006 & http://www.pilcomayo.net/media/uploads/biblioteca/libro_78_EP-078.pdf & libro_78_EP-078.pdf & $\begin{array}{l}\text { Integrated Management Project for the Iturata River Basin in the municipality } \\
\text { of Sacaca Fasel - Phase I- year 2006-Bolivia }\end{array}$ \\
\hline $\begin{array}{l}\text { Proyecto Manejo Integral de la cuenca del río Huaraya en el Municipio de } \\
\text { Sacaca Fase 1-año 2006-Bolivia }\end{array}$ & 2006 & http://www.pilcomayo.net/media/uploads/biblioteca/libro_80 EP-080.pdf & libro_80_EP-080.pdf & $\begin{array}{l}\text { Integral Management Project of the Huaraya river basin in the Municipality of } \\
\text { Sacaca Phase } 1 \text {-year 2006-Bolivia }\end{array}$ \\
\hline $\begin{array}{l}\text { Proyecto Manejo Integral de la Cuenca del río Ticanoma Fase 1- año 2006- } \\
\text { Bolivia }\end{array}$ & 2006 & http://www.pilcomayo.net/media/uploads/biblioteca/libro_81_EP-081.pdf & libro_81_EP-081.pdf & $\begin{array}{l}\text { Integral Management Project of the Ticanoma River Basin Phase 1- year } 2006 \\
\text { Bolivia }\end{array}$ \\
\hline $\begin{array}{l}\text { Linea Base Ambiental y Socioeconómica de la Cuenca del rio Pilcomayo- } \\
\text { Informe Final: Anexos: Mapas }\end{array}$ & 2007 & http://www.pilcomayo.net/media/uploads/biblioteca/libro 872_MA-241.rar & mapas.pdf & $\begin{array}{l}\text { Environmental and Socioeconomic Baseline of the Pilcomayo River Basin- } \\
\text { Final Report: Annexes: Maps }\end{array}$ \\
\hline $\begin{array}{l}\text { Linea Base Ambiental y Socioeconómica de la Cuenca del rí Pilcomayo- } \\
\text { Informe Final: Tomo I - Contexto y Desarollo de los LBAYS } \\
\text { caracterizacion del Area de Estudio : } 13 \text { La Ictofauna y la Problematica } \\
\text { Pesquera }\end{array}$ & 2007 & http://www.pilcomayo.net/media/uploads/biblioteca/libro_873_MA-242.rar & ParteII13Ictiofaunayproblemaspesquerosfinal.pdf & $\begin{array}{l}\text { Environmental and Socioeconomic Baseline of the Pilcomayo River Basin- } \\
\text { Final Report: Volume I-Context and Development of the LAAYS } \\
\text { Characterization of the Study Area: } 13 \text { The Ichthyofauna and the Fishing } \\
\text { Problem }\end{array}$ \\
\hline $\begin{array}{l}\text { Linea Base Ambiental y Socioeconómica de la Cuenca del río Pilcomayo- } \\
\text { Innforme Final : Tomo III - - los Conflictos Ambientales de la Cuenca del } \\
\text { Pilcomayo: } 4.6 \text { Procesos de Degradación Ambiental }\end{array}$ & 2007 & http://www.pilcomayo.net/media/uploads/bibliotecalibro 874_MA-243.rar & ParteIII4.6degradacionambientalfinal.pdf & $\begin{array}{l}\text { Environmental and Socioeconomic Baseline of the Pilcomayo River Basin- } \\
\text { Final Report: Volume III - The Environmental Conflicts of the Pilcomayo } \\
\text { Basin: 4.6 Environmental Degradation Processes }\end{array}$ \\
\hline $\begin{array}{l}\text { Línea Base Ambiental y Socioconónimica de la Cuenca del río Pilcomayo- } \\
\text { Informe Final : Tomo III - los Conflictos Ambientales de la Cuenca del } \\
\text { Pilcomayo: } 4.7 \text { Degradación del Recurso Pesquero }\end{array}$ & 2007 & http://www.pilcomayo.net/media/uploads/biblioteca/libro_874_MA-243.rar & ParteIII4.7Pescafinal.pdf & $\begin{array}{l}\text { Environmental and Socioeconomic Baseline of the Pilcomayo River Basin- } \\
\text { Final Report: Volume III - The Environmental Conflicts of the Pilcomayo } \\
\text { Basin: } 4.7 \text { Degradatation of the Fishing Resource }\end{array}$ \\
\hline $\begin{array}{l}\text { Línea Base Ambiental y Socioconómimica de la Cuenca del río Pilcomayo- } \\
\text { Informe Final :Tomo III - los Conflictos Ambientales de la Cuenca del } \\
\text { Pilcomayo: 4.8 Pérdida de Hábitat y Biodiversidad }\end{array}$ & 2007 & http://www.pilcomayo.net/media/uploads/bibliotecalibro_874_MA-243.rar & ParteIII4.8Biodiversidadfinal.pdf & $\begin{array}{l}\text { Environmental and Socioeconomic Baseline of the Pilcomayo River Basin- } \\
\text { Final Report: Volume III - The Environmental Conflicts of the Pilcomayo } \\
\text { Basin: } 4.8 \text { Loss of Habitat and Biodiversity }\end{array}$ \\
\hline $\begin{array}{l}\text { Línea Base Ambiental y Socioeconómica de la Cuenca del río Pilcomayo- } \\
\text { Informe Final :Tomo III - los Conflictos Ambientales de la Cuenca del } \\
\text { Pilcomayo: } 6.2 \text { Análisis Integrado de Problemáticas } \\
\end{array}$ & 2007 & http://www.pilcomayo.net/media/uploads/biblioteca/libro_874_MA-243.rar & ParteIII6Integraciondelasproblematicasfinal.pdf & $\begin{array}{l}\text { Environmental and Socioeconomic Baseline of the Pilcomayo River Basin- } \\
\text { Final Report: Volume III - The Environmental Conflicts of the Pilcomayo } \\
\text { Basin: } 6.2 \text { Integrated Problems Analysis }\end{array}$ \\
\hline $\begin{array}{l}\text { Plan maestro de gestión integrada de la cuenca del Río pilcomayo: } \\
\text { Documento base resultante del proceso de socialización }\end{array}$ & 2010 & http://www.pilcomayo.net/media/uploads/biblioteca/libro_1374_PP-070.pdf & libro_1374_PP-070.pdf & $\begin{array}{l}\text { Master plan for the integrated management of the Pilcomayo river basin: Base } \\
\text { document resulting from the outreach process }\end{array}$ \\
\hline $\begin{array}{l}\text { Primer Taller Técnico en Paraguay: Formulación del Plan Maestro de la } \\
\text { Cca. del Río Pilcomayo }\end{array}$ & 2007 & http://www.pilcomayo.net/media/uploads/biblioteca/libro_624_LG-122.pdf & libro_624_LG-122.pdf & $\begin{array}{l}\text { First Technical Workshop in Paraguay: Formulation of the CCA Master Plan } \\
\text { of the Pilcomayo River }\end{array}$ \\
\hline
\end{tabular}


Appendix 3. Concept relationships frequency chart

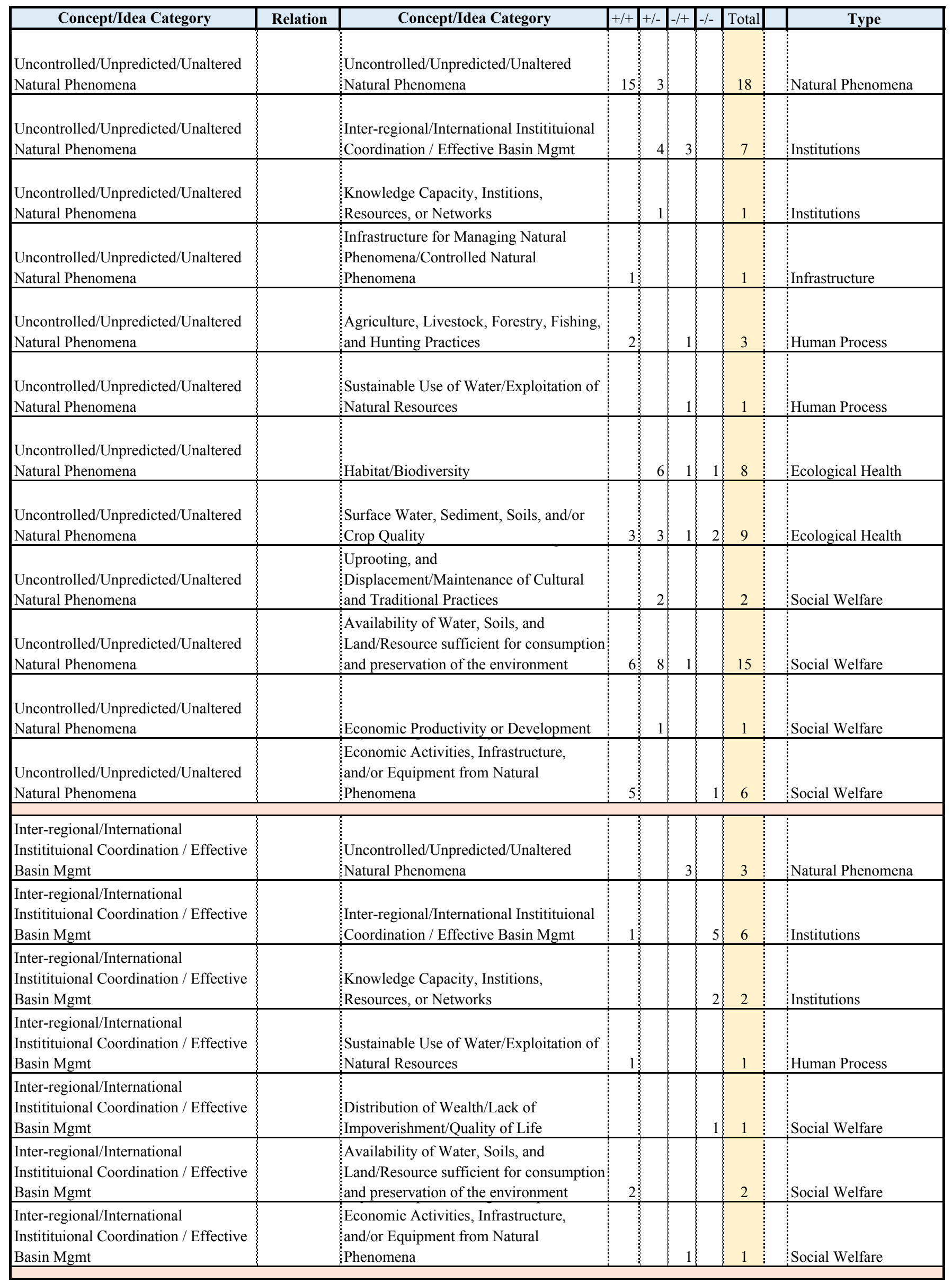




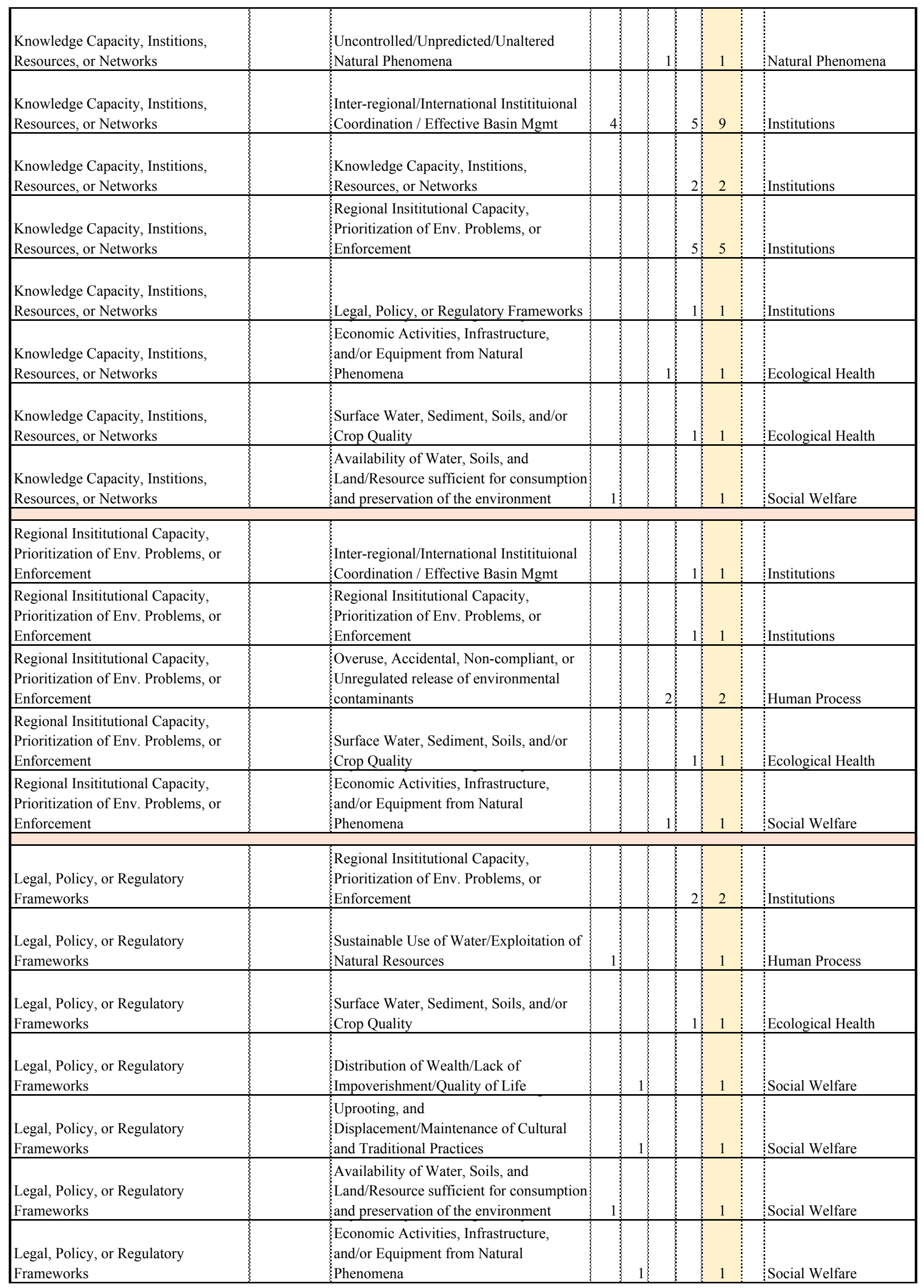




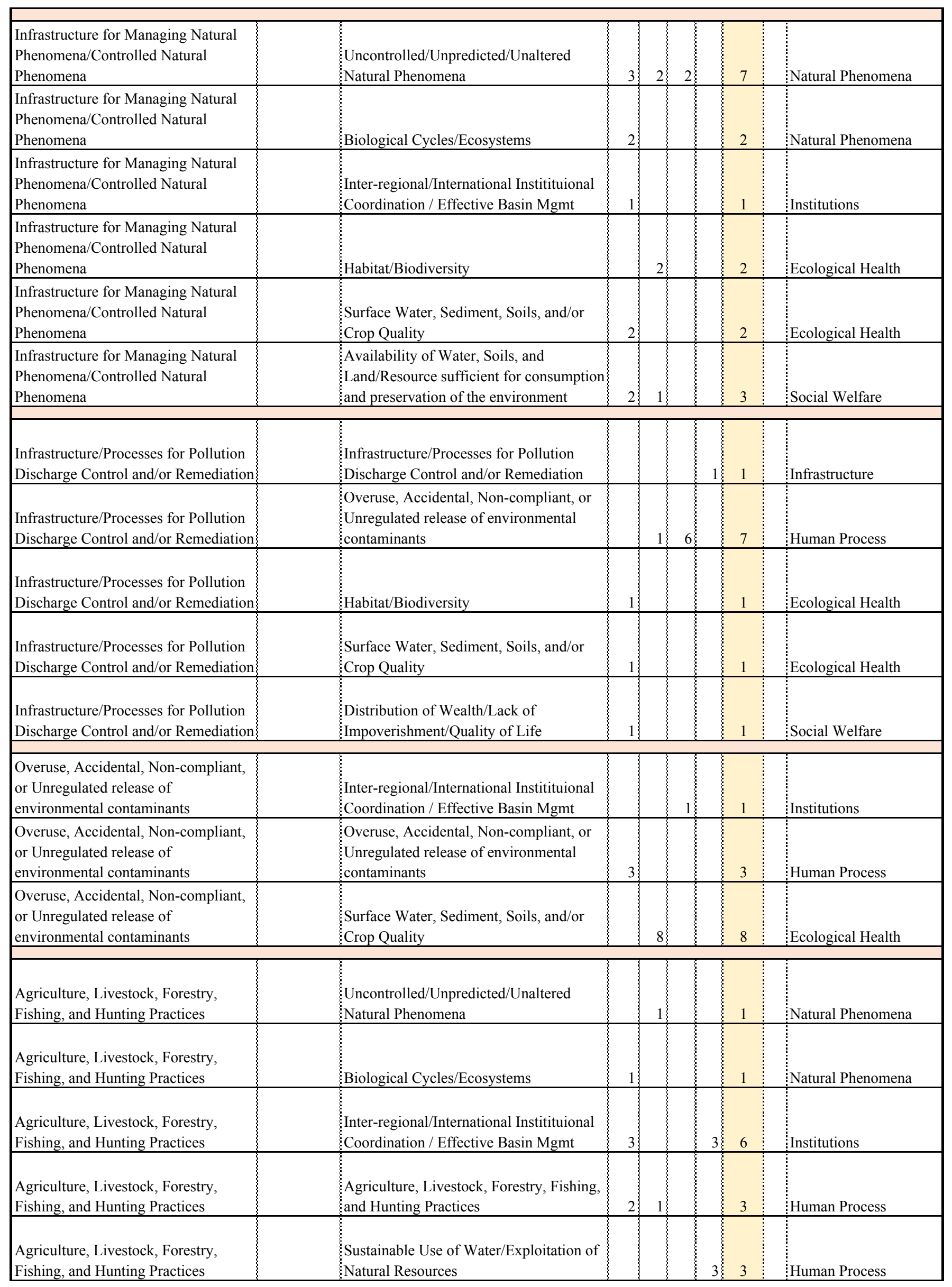




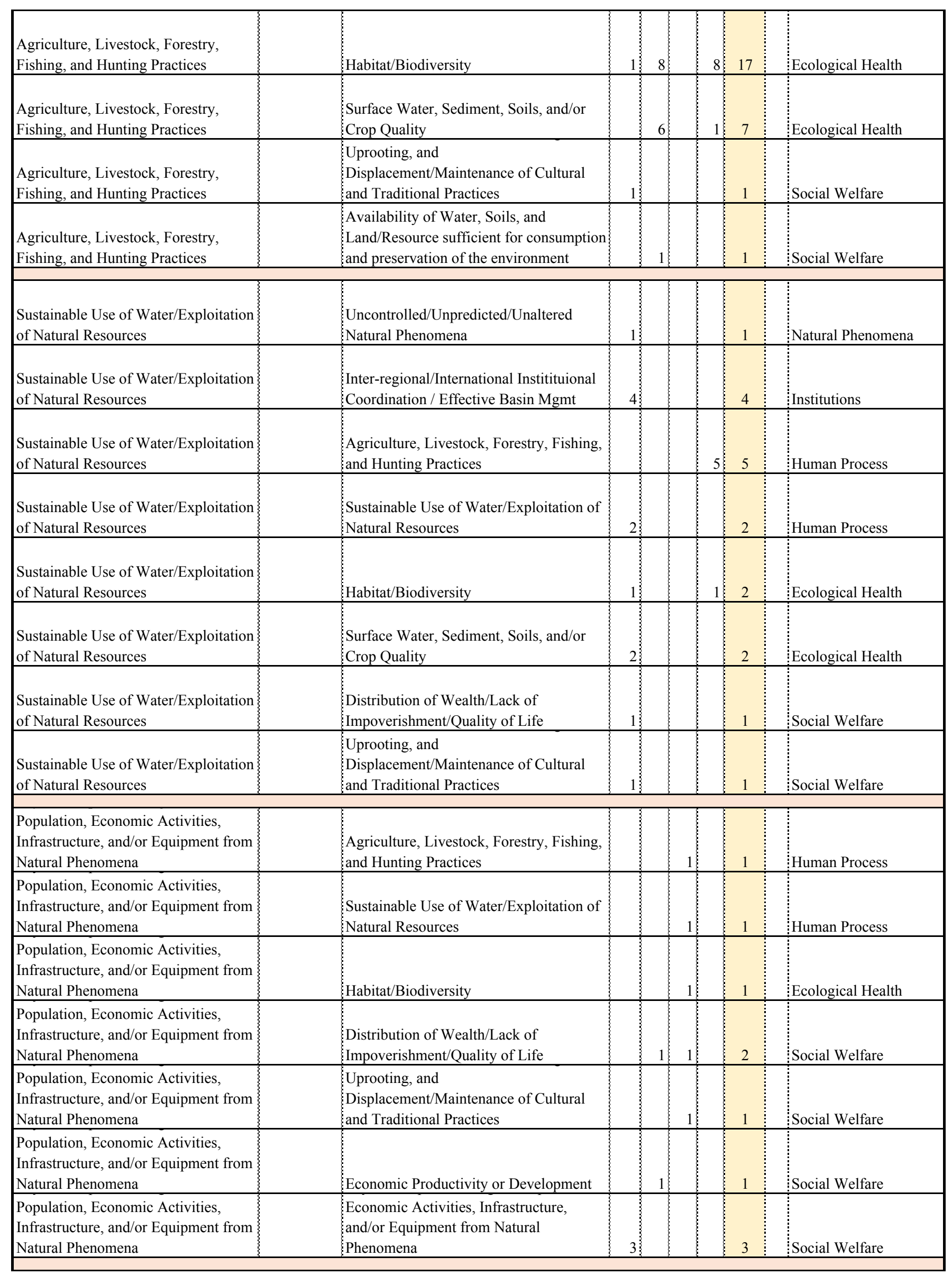




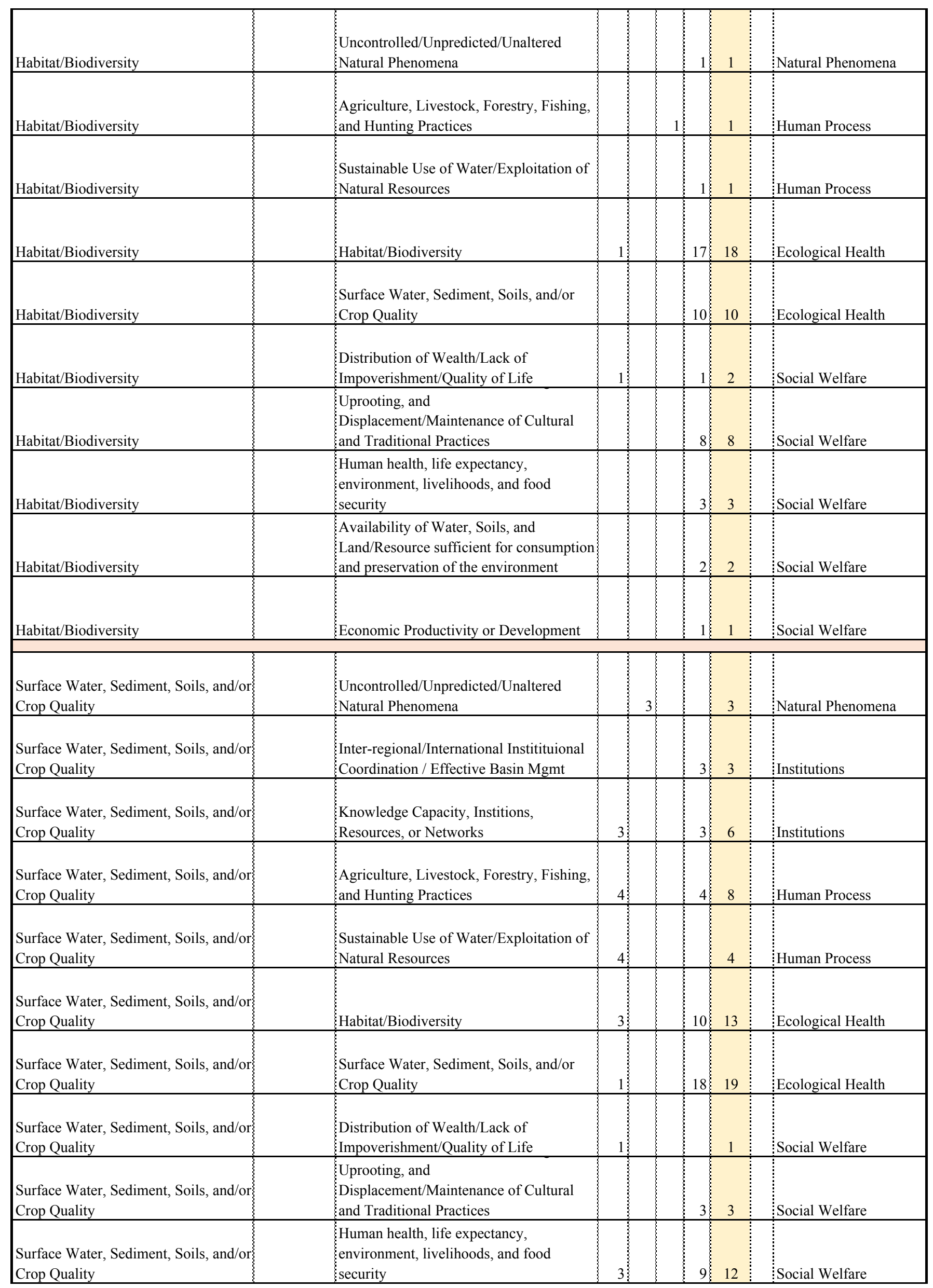




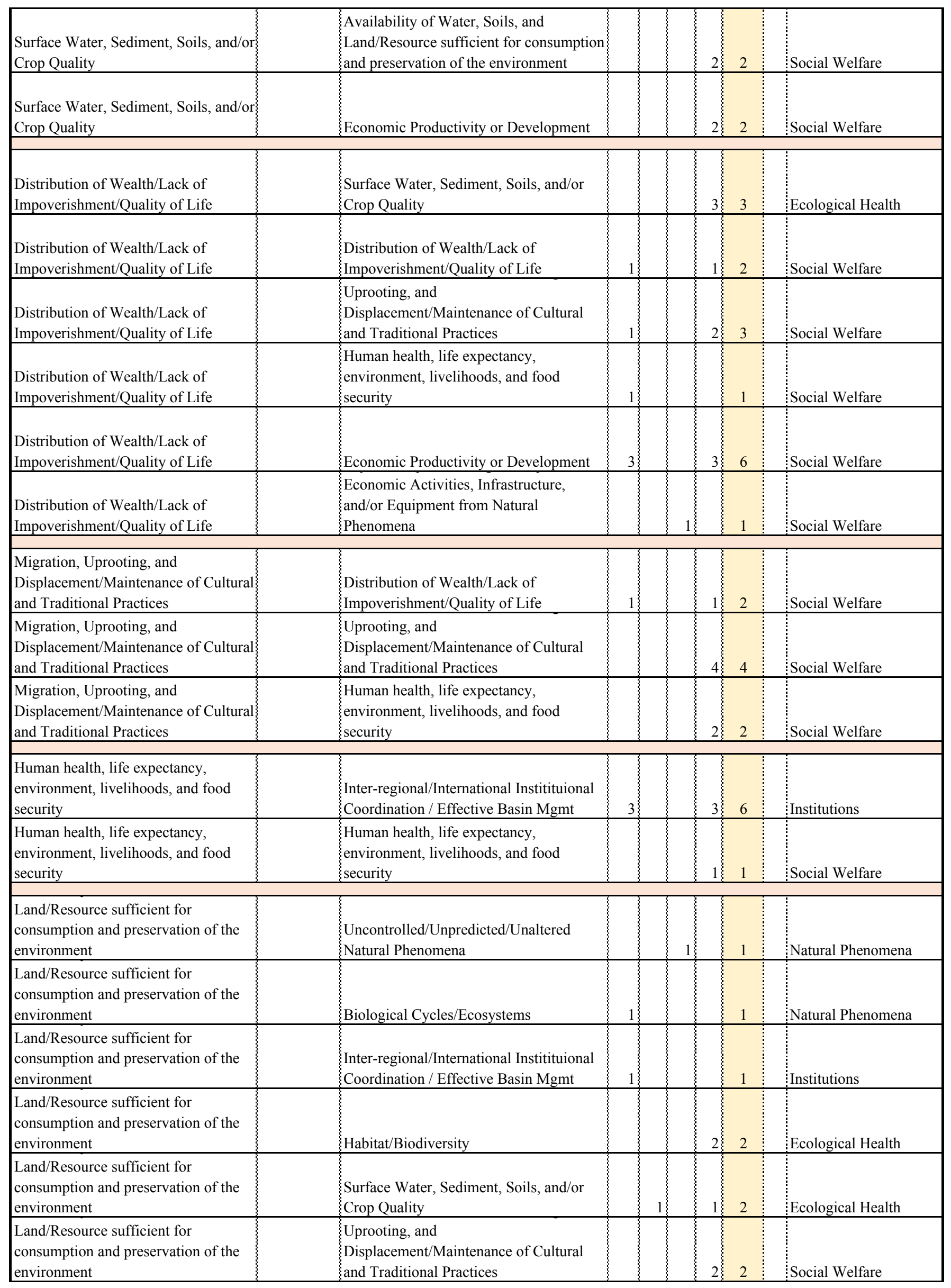




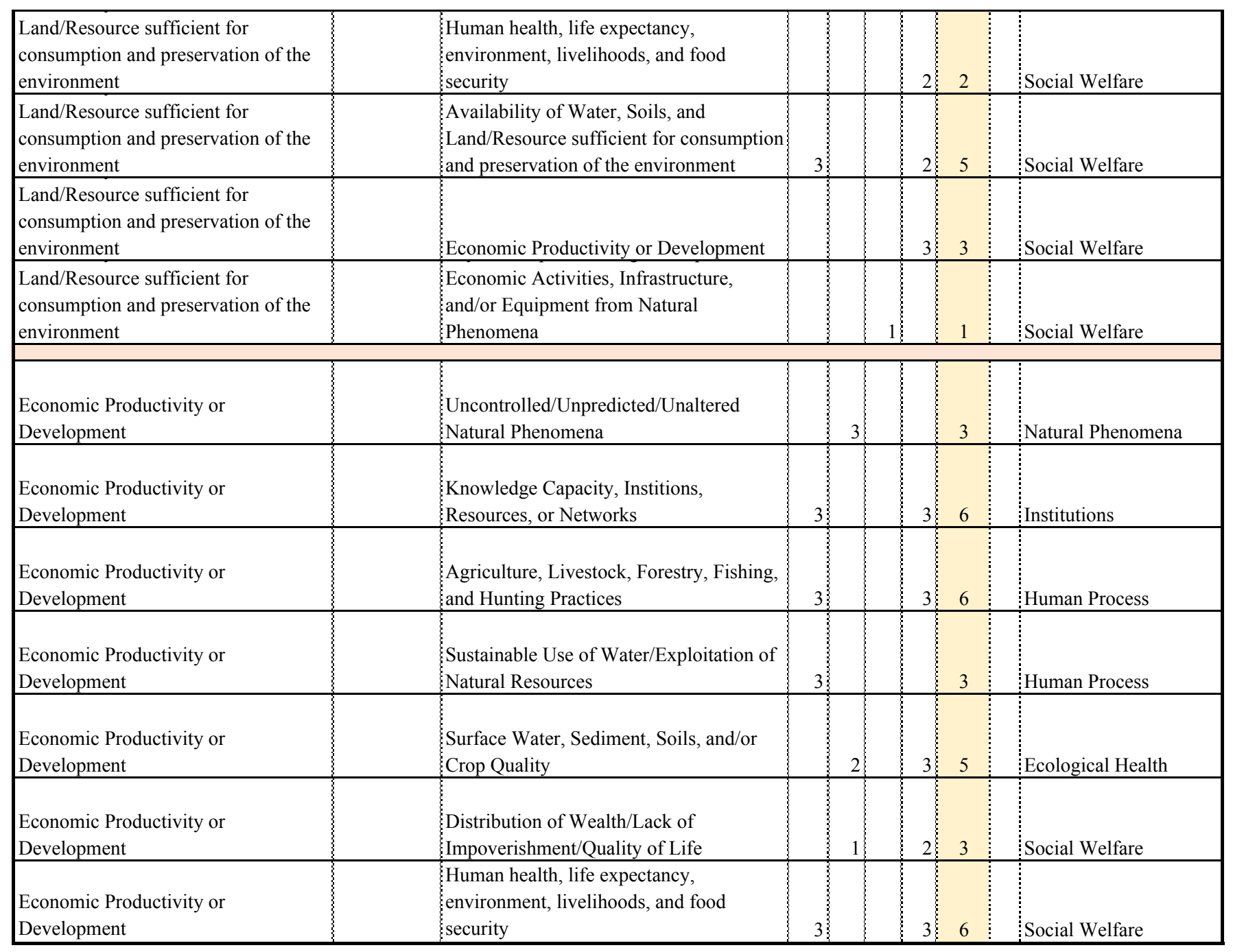

